\title{
Timelines of Creativity: A Study of Intellectual Innovators in Information Science
}

\author{
Blaise Cronin and Lokman I. Meho \\ School of Library and Information Science, Indiana University, Bloomington, IN 47401 \\ E-mail: \{bcronin, meho\} @indiana.edu
}

\begin{abstract}
We explore the relationship between creativity and both chronological and professional age in information science using a novel bibliometric approach that allows us to capture the shape of a scholar's career. Our approach draws on Galenson's (2006) analyses of artistic creativity, notably his distinction between conceptual and experimental innovation, and also Lehman's (1953) seminal study of the relationship between stage of career and outstanding performance. The data presented here suggest that creativity is expressed in different ways, at different times and with different intensities in academic information science.
\end{abstract}

\section{INTRODUCTION}

Creativity announces itself in different ways and at different times in the lives of scientists, writers and performers. Harvey Lehman's seminal study of more than half a century ago established in authoritative fashion the relationship between chronological age and outstanding performance for a very wide variety of intellectual, artistic and sporting activities (Lehman, 1953). He provided, inter alia, the age ranges within which chemists, mathematicians, astronomers, geologists, botanists, psychologists and many others develop their most original and influential ideas. Lehman generalizes thus: "the maximum production rate for output of highest quality usually occurs at an earlier age than the maximum rate for less distinguished works by the same individual” (Lehman, 1953, p. 326). Summarizing a vast body of data, we can say that scientists and scholars typically make their major contributions at a relatively early stage in their careers and that there are sometimes notable differences in the age-innovation relationship both across and within disciplines.

Recently, David Galenson explored human creativity in the art world. In a series of studies (encapsulated in Galenson, 2006) he identified two distinct forms of artistic innovation: experimental and conceptual. His research builds on the earlier investigations of Lehman, who devoted a chapter of his 
book, Age and Achievement, to plotting “performance age-curves” for artists and architects (Lehman, 1953, pp. 70-85). In short, Galenson found that there are painters who produce experimental innovations (think slow and incremental) and others who produce conceptual innovations (think fast and spectacular): Rembrandt and Cézanne are examples of the former group, Picasso and Warhol the latter. However, Galenson (2004, p. 126) recommends that the experimentalist/conceptualist distinction should be viewed "not simply as a binary categorization but instead as a continuum," adding that the two broad categories may both comprise “extreme and moderate” practitioners (p. 124). One of Galenson’s key findings is that “important conceptual painters produce famous individual masterpieces, but great experimental painters do not, instead producing important bodies of work" (Galenson, 2003a, p. 14; italics added). Another is that experimentalists tend to produce "their best work late in their careers" while conceptualists tend to make “their greatest contributions early” (Galenson, 2003a, p. 14; italics added).

There are, as Galenson (2003b, p. 18) notes, similarities between artists and academics: "Like the research scholar, the modern artist's goal is to innovate- to produce new methods and results that change the work of other practitioners.” Furthermore, the "greatest artists are obviously not those who produce the most works, or even those who produce the most good works, but rather those who produce the works of greatest importance” (Galenson, 2005a, p. 5). In that respect, artists and academics have a common goal: to influence their peers, their primary audience. In the art world, peer recognition and expert judgment correlate positively with art auction prices (Galenson, 2005a). In academia, peer recognition correlates positively with citation counts (e.g., Garfield \& Welljams-Dorof, 1992; Smith \& Eysenck, 2002). Reading Galenson's studies caused us to wonder if, for instance, two discrete patterns of agerelated innovation, comparable with those he discovered in his art historical studies, might also be found among academic researchers. We are not positing direct equivalence between artists and authors, nor do we really expect to unearth the clear-cut differences between conceptualists and experimentalists that Galenson did-dramatic innovation in art is possible in part because the rules and conventions of art, unlike the rules of science, can, given a healthy cocktail of imagination and self-confidence, simply be 
brushed aside: just think of Cubism or Dada. However, we do acknowledge that Galenson's overarching theoretical framework both stimulated and shaped our thinking.

\section{APPROACH AND METHODS}

We present here a preliminary bibliometric exploration of the creative life cycles of leading information scientists. Our approach can be applied to any discipline or field; we have chosen for reasons of convenience to work with a community we know well.

Galenson identified important artists and their most influential paintings by counting how often their works were reproduced in leading art history books. Reproductions function, in effect, as citations, allowing one to rank both different artists' relative perceived significance and also to establish the degree of consensus among art historians, critics and curators as to individual artists' most important paintings (Galenson, 2003b, pp. 26-27). Some great artists are synonymous with iconic paintings (Picasso with Les Demoiselles d'Avignon and Guernica, for example), while other members of the pantheon are not: “Mondrian was a master without a dominant masterpiece,” as Galenson (2005b, p. 9) observes pithily. In addition, there are those, such as Géricault and Grant Wood (The Raft of the Medusa and American Gothic, respectively) whom Galenson (2005c) describes as "one-hit wonders," a phenomenon that certainly is not peculiar to painters.

This modest study is a first attempt to look for information science’s Picassos, Mondrians and Géricaults. Our focus, it need hardly be said, is on publications rather than paintings. Naturally, we caution against over-drawing the parallels between the products and personalities of the two worlds. For instance, co-authorship is common practice in many academic disciplines, but co-creation in the plastic arts is not: there are, to be sure, exceptions (Gilbert \& George and the Chapman brothers are major figures in the contemporary British art scene) and, of course, some celebrated artists, from Rubens to Warhol, relied to a greater or lesser extent on the painterly and production skills of members of their atelier or entourage, but when we think of painting we think typically of originary genius and individual expression. 
Instead of counting how often canonical artists’ works are reproduced, we count the frequency with which notable information scientists' publications are cited over time; instead of identifying the most frequently reproduced paintings, we identify the most highly cited publications within an author's output. We also determine when these works were produced (early or late in an author's career) and calculate their relative impact in order to explore, as Galenson (2006, pp. 23-24) did, the relationship between stage of life and quality of work.

Now, in fields such as physics or biology, as Lehman (1953) demonstrated, it is not difficult to identify papers or patents reporting discoveries which have had an impact on the scientific community equivalent to that of, say, Jasper Johns's Flag or Andy Warhol's Campbell's Soup Can on the development of modern art. Authors of such blockbusters will not only be highly cited over time, but will have accumulated encomia and prizes of one kind or another, just as leading artists do. Information science-and in saying this we trust we are not held to be suffering from physics envy — is a much humbler enterprise than either the physical or life sciences and little of the field's research radically changes the way we view the world. Nonetheless, it is not unreasonable to assume that among the lifetime contributions of the field's grandees there will be some publications (“individual masterpieces," to use Galenson's term) that have had exceptional intra-field impact, papers that have shaped or redirected thinking within particular specialties or, alternatively, a corpus ("body of work”) that has been cumulatively influential (see Bates, 2005). We would note in passing that scholars in information science tend not to have significant extra-field impact (Cronin \& Pearson, 1990).

We want to find out what those "masterpieces" are, who produced them and when they were published, in the process establishing whether our sample of grandees - the presumptive innovators of the title-belong to the broadly defined experimentalist or conceptualist category, or neither. This approach is quite different in intention from our recent application of the $h$-index to a number of leading information scientists (Cronin \& Meho, 2006). We are not here focusing primarily on individual scholars' citation counts or undertaking comparative rankings; rather we are looking for general patterns, or timelines, of 
creativity within a particular intellectual community. In short, we are using citation data to capture the shape of people’s careers-performance age-curves in Lehman's language.

Our sample of a dozen academics is drawn from the lists of those who have won either the ASIST (American Society for Information Science and Technology) Award of Merit (the Society's highest honor) or the Research in Information Science award, or both (for background information on these awards, see: http://www.asis.org/awards/winners.html). All twelve individuals-Marcia Bates, Nicholas Belkin, Blaise Cronin, Raya Fidel, Paul Kantor, Carol Kuhlthau, Gary Marchionini, Tefko Saracevic, Dagobert Soergel, Don Swanson, Carol Tenopir and Howard White-are recognizable members of the information science community and active researchers. Even those who are officially retired (e.g., Bates, Swanson) continue to conduct research and publish regularly in the scholarly literature. Two members of our sample (Kantor, Swanson) trained as physicists before switching to information science and both have a small number of publications in the mainstream physics literature. The youngest author in the mix is Tenopir (54), the oldest Swanson (82). The average age is 65.

We used several biographical sources (e.g., Biography and Genealogy Master Index), a number of databases (e.g., Dissertations and Theses) and the curricula vitae of the authors to collect year of birth and dissertation information. We used Web of Science and the authors' lists of publications to identify high-impact works and compute cumulative citation counts. The lists of publications were particularly useful in the cases of those authors with relatively common names (e.g., Cronin, Swanson, White) and those who made a switch in their careers. The lists of publications were also useful for accurately identifying citations to non-journal items (e.g., conference papers, chapters, monographs and reports) as these types of materials are often cited by authors, and consequently entered into Web of Science, in a variety of different ways.

Because we wanted to establish the relationship between age (chronological and professional) and creativity for each author, we limited our analysis to items in which our sample members were first authors. Citations to works with multiple editions (e.g., Kuhlthau’s 1993 and 2003 Seeking Meaning) were merged into one count and credited for the year in which the book first appeared. Citations to 
journal articles published in parts were also merged into one count—e.g., Belkin (1982), Fidel (1991) and Saracevic (1988)—see the Appendix for a full listing of works. Self-citations, which on average account for approximately 7\% of the total citations of an author in information science (Cronin \& Meho, 2006), are included in this study. The data were collected twice to ensure accuracy (both times in September 2006).

\section{RESULTS AND DISCUSSION}

We gathered two kinds of data for each author in our sample: (i) the number of high-impact works (masterpieces, to sustain the painterly analogy), and (ii) cumulative citation counts (a proxy for reputation or public visibility) from the date of the author's first citation in Web of Science (see Table 1). The counts are limited to first author items. High-impact works were those cited 40 times or more. The definition is, of course, arbitrary, but for a small field such as information science it seems not unreasonable. For each author we show the date of publication and the number of citations accruing to each high-impact work. The date at which authors were awarded their Ph.D. is also indicated on both timelines; the average age was 33.

Professional age is usually defined as age since award of doctorate. We modified this approach very slightly because a couple of individuals (Belkin, Cronin) had produced highly cited works prior to completion of their Ph.D. (see Table 1). In this paper we show authors' creativity by stage of career (mid, early, late). The number of high-impact works for each stage and the percentage of total citations accounted for by those works are shown in Table 2. We define early career as up to 10 years post-Ph.D., mid-career as the subsequent decade, and late career as all years thereafter. Together, Tables 1 and 2 allow the reader to view each author's creativity as a function of both chronological and professional age.

Visual inspection of Table 1 (high-impact works) allows us to see at a glance when different scholars produced their most influential works (chronological and professional age are recorded on the horizontal axis), how many significant works were produced over the course of a career, and also the frequency with which each of their high-impact papers was cited (the vertical axis). The range for high- 
impact works was 2 to 14: Belkin had both the largest number of high-impact papers as well as the single most highly cited publication (Belkin, Oddy \& Brooks, 1982), which was cited 261 times. The complete list of highly cited works ( $\mathrm{N}=74)$ is shown in the Appendix; Table 4 lists these works by place of publication. Some 22 of the highly cited works (30\%) were published in the Journal of the American Society for Information Science, six appeared in the Journal of Documentation, three each in Information Processing \& Management, Journal of Information Science, Library Quarterly and Online Review, and two each in Library \& Information Science Research, Perspectives in Biology and Medicine and Proceedings of the ASIS Annual Meeting. The rest were singletons, with the exception of nine books and two book chapters.

The second set of plots in Table 1 shows the cumulative citation counts for each author. The range in this case was 295 to 1,122. Once again, visual inspection allows us to appreciate differences in the gradients of the curves and the points at which inflections occurred over the trajectory of an author's academic career. At the risk of stating the obvious, we would note that, all things being equal, those who have been in the field longest should have the highest citation counts. Given the age range (54-82), the late stage of a career can vary appreciably in terms of elapsed time; for example, Swanson's late career began in 1972 while Tenpoir’s started in 2004.

The 12 timelines describe the shape of each author's career. These are quite varied. Belkin's profile looks like the Manhattan skyline, attesting to persistent influence over more than a quarter century. White's profile is rather different, with three periods of particularly significant activity, in his 30s, 40s and 50s. In Kuhlthau's case, her high-impact publications came relatively late in life (her Ph.D. was awarded at a correspondingly late age, 46), but early in terms of her professional career. Some $86 \%$ of her total citations are to high-impact works she published within 10 years of receiving her Ph.D. This is higher than any other individual: Belkin (59\%) and Fidel (51\%) came next (see Table 2).

Saracevic produced four of his seven high-impact publications between the ages of 58 and 66, when many scholars might be tempted to throttle back. Bates, Saracevic and White's high-impact publications are distributed more or less equally across their time-in-field (see Tables 1 and 2). Swanson 
produced his most influential works in the twilight of his career, in his 60s and 70s. In the cases of Cronin and Fidel, high-impact publications occur around the time the terminal degree is awarded, though both have continued to produce high-impact works into their fifties. This is as one might expect; the doctorate represents a major investment of time and intellectual energy and it is often a launch pad for a research program that results in sustained, downstream publication, as we see with Belkin.

One thing is clear from the data: this is not a field that produces Wunderkinder, brilliant young things who make their mark at a precocious age. In fact, some of our sample members have kept their best wine until last. Creativity in academic information science is clearly not the preserve of callow youth and no one pattern of productivity characterizes the innovators in our sample. Stage of life and quality of work do not at first blush appear to be tightly coupled. Additionally, the data seem to support Adkins and Budd's (2006, p. 384) contention that "productive faculty tend to remain productive throughout their careers, and that faculty whose research is highly cited remain influential throughout their careers.”

However, it might be countered that the evolution of the Internet and World Wide Web has resulted in numerous opportunities for, and concrete examples of, innovation and entrepreneurial verve by young minds and that our study is, to quote one referee, "restricted by construction to senior members of the profession.” We do not for a moment deny that the Internet has stimulated waves of creativity; one has only to think of youthful, household names such as Marc Anderssen (developer of Mosaic), Sergey Brin and Larry Page (co-founders of Google), and Jimmy Wales (founder of Wikipedia). But each of these creative minds dropped out of university in order to pursue their dreams unfettered by the norms and expectations of academe. Their insights and inventions will likely have much greater impact on society-at-large than the contributions of any or all of the twelve professors in our sample. But that is to miss the point of the present study, which focuses on patterns of productivity and creativity within a traditional academic environment, where, often but by no means always, an author's scholarly contributions (often but not always publications) and impact can only be assessed with the benefit of hindsight. To return to the analogy with art for a moment: Andy Warhol was indeed recognized as an enfant terrible during his lifetime, but it is only by posthumous analysis of his legacy (as reflected in 
exhibitions, sale room prices, etc.) that one can appreciate fully the enduring nature of his innovative, conceptual contributions, relative to his coeval peers and also other artists of historical note. Not all young turks’ stars burn brightly and persistently (Damien Hirst is one whose reputation continues to glow, but for every Hirst there are many six-day wonders); some fade quickly from view and others simply fall from grace as fashions and evaluative criteria change.

When we turn our attention to the cumulative frequency data (Table 1) we see that an author can have a high citation count (body of work) but a relatively low number of high-impact publications (individual masterpieces). For example, Tenopir has only two high-impact publications (separated in her case by 15 years) yet her career output has attracted 718 citations in total. One reason for this kind of profile is the inclusion of citations to columns or op ed pieces in professional journals, in addition to citations earned by scholarly publications (see Adkins \& Budd, 2006, p. 378; Meho, \& Spurgin, 2005, p. 1328). Marchionini, for his part, has five high-impact publications, but none in the last decade, yet his cumulative citation count (774) continues to grow steadily. This is also the case with Kantor and Soergel. Combined, the histograms and cumulative frequency distributions allow us to develop a more nuanced understanding of the nature and stages of scholarly creativity.

Table 3 shows the proportion of citations accounted for by each author's high-impact publications. The number of such works ranges from 2 to 14, the percentage of total citations ranges from $17 \%$ to $86 \%$. Some authors' citations are concentrated on a set of high-impact papers: Kuhlthau's six and White's seven publications account for $86 \%$ and $73 \%$ of all citations to their work, respectively. Other authors exhibit moderate concentration: Swanson's nine and Marchionini's five high-impact publications account for $55 \%$ and $67 \%$, respectively, of their totals. Almost half (49\%) of Soergels' citations are attributable to two high-impact publications, whereas Tenopir's brace accounts for only $17 \%$ of her career citation count. These data suggest that in some cases (e.g., Bates, Belkin, Kuhlthau, White) a relatively small body of work accounts for much of a scholar's overall impact on the field's thinking —a classic Pareto-like distribution. In other cases, an author's impact may be less closely associated in the minds of 
his or her peers with a small cluster of publications than with a significant body of work distributed over the course of a career (e.g., Kantor, Tenopir).

Several scholars (Belkin, Cronin, Saracevic, Soergel, White) produced one work that accounted for $20 \%$ or more of their total citations within a decade of being awarded their Ph.D. Belkin’s most highly cited work, ‘ASK for information retrieval,' was published five years after he received his Ph.D; Cronin’s most highly cited work, The Citation Process was published a year after he received, his Ph.D.; Kuhlthau's most highly cited work, 'Inside the search process,' was published eight years after she was awarded her Ph.D.; Saracevic's most highly cited work, 'Relevance: Review of and a framework for the thinking on the notion in information science' was published five years after completion of his doctorate; Soergel's most highly cited work, Indexing Languages and Thesauri: Construction and Maintenance, was published fours years after he was awarded his D.Phil.; White’s most highly cited paper, ‘Author cocitation: A literature measure of intellectual structure,' which was coauthored with Griffith, appeared seven years after he received his Ph.D. It is not unreasonable to label these seminal contributions (with perhaps the exception of Soergel's textbook) as essentially conceptual in character; they review existing theories and models and provide new ways of seeing or framing persistent problems, whether in information retrieval, information seeking or citation analysis. Of course, the fact that several of these scholars have produced important theoretical work relatively early in their careers does not make them out-and-out conceptualists; most have also subsequently produced empirical work of one kind or another that tests or extends their early theoretical contributions.

Others in our sample (Kantor, Swanson, Tenopir) do not have in their portfolio a single work that accounts for as much as $15 \%$ of their total citations. Kantor's most highly cited work is a monograph, Objective Performance Measures for Academic and Research Libraries; his only other highly cited work appeared in the physics literature a year after he completed his Ph.D. Swanson's profile is ostensibly that of an experimentalist. Relatively late in his career he undertook empirical research to ground his influential concept of logically related but non-interconnecting literature sets, first laid out in his most highly cited paper, Undiscovered public knowledge. This was published a quarter century after Swanson 
was awarded his Ph.D. Tenopir's most highly cited work, Towards Electronic Journals: Realities for Scientists, Librarians, and Publishers, was published 15 years after she received her Ph.D. These three authors are perhaps more appropriately classified as experimentalists than conceptualists, if we are to stick with a simple binary.

The three remaining members of the sample are Bates, Fidel and Marchionini. Bates produced her most influential paper, 'The design of browsing and berrypicking,' which accounts for more than 20\% of her citations, 17 years after being awarded her Ph.D. Fidel's most highly cited paper, 'Searchers' selection of search keys,' accounts for approximately $18 \%$ of her total citations and was published nine years after she was awarded her doctorate. Marchionini published his most cited work, a textbook entitled Information Seeking in Electronic Environments, 14 years after receiving his Ph.D. His other highly cited works are mainly empirical in character.

Earlier, we characterized this distinction in the art world as conceptual vs. experimental innovation. Of course, the material practices and, indeed, motivations of painters and professors differ in important respects. Some artists may simply have chosen not to refine or rework a particular technique or motif (as did Cezanne, Mondrian and Pollock) but instead intentionally address a diversity of topics and themes over the course of a career. Some authors in our sample (the Picassos and Warhols of information science, if you will) have produced works that have had a demonstrably significant impact on teaching and research. This is shown clearly in the Appendix that lists all the high-impact publications featured in our study. In some cases, one could almost substitute a concept for an author's name (e.g., Bates and berry-picking; Belkin and ASK—anomalous states of knowledge; Kuhlthau and ISP_information search process; White and co-citation analysis). We are not for a moment suggesting that Bates is synonymous with a noun or that Belkin is reducible to an acronym, but making the point that some people are very closely associated with certain key ideas that have influenced collective thinking and awareness in the field—one thinks here, by way of parallel, of Small's (1978) characterization of cited documents as “concept symbols.” 
Such individuals are close to what Galenson had in mind when he spoke of conceptual innovators. Other authors (experimentalists) have a more diffuse effect on their peers, calling to mind the comment of the photographer Annie Leibovitz (2006, p. 61), who said: “I’ve always thought the strength of my work has been in the body of the work." For her, the cumulative effect of her oeuvre takes precedence over the production of individual pieces that stand out. This can also be said of several of those in our sample (e.g., Kantor, Tenopir) whose contributions are perhaps more dispersed and varied in nature than those of others. We say 'perhaps' because such a statement can only be made with confidence if one has checked every item in each author's bibliography and determined the degree of topic coverage and overlap.

\section{CONCLUSIONS}

Our data suggest that there may be two (very) broad categories of innovators in information science, just as Galenson found in his analyses of the history of art, but we-as he-would argue that it makes more sense to view creativity as a continuum, running from predominantly conceptual to predominantly experimental. In addition, it seems abundantly clear from our survey that intellectual innovation is not a function of chronological age alone. The high-impact publications, not all of which are conceptual in character, produced by the dozen information scientists in our sample do not cluster neatly at either the opening or concluding stage of a career. Rather, the data in Tables 1 and 3 suggest that creativity is expressed in different ways, at different times and with different intensities. Even if no one model fits, our fine-grained analysis of publication and citation data helps us better appreciate the nature of creative activity within information science and the various ways in which intellectual impact is exhibited over the lifecycle of an academic career.

\section{ACKNOWLEDGMENT}

We are grateful to Debora Shaw for reading an early draft and to an anonymous referee for a number of extremely thoughtful comments and helpful suggestions. 


\section{REFERENCES}

Adkins, D., \& Budd, J. (2006). Scholarly productivity of U.S. LIS faculty. Library \& Information Science Research, 28(3), 374-389.

Bates, M. J. (2005). Information and knowledge: an evolutionary framework for information science. Information Research, 10(4). Available at: http://InformationR.net/ir/10-4/paper239.html]

Cronin, B., \& Meho, L. (2006). Using the $h$-index to rank influential information scientists. Journal of the American Society for Information Science and Technology, 57(9), 1275-1278.

Cronin, B., \& Pearson, S. (1990). The export of ideas from information science. Journal of Information Science, 16(6), 381-391.

Galenson, D. W. (2006). Old Masters and Young Geniuses: The Two Life Cycles of Artistic Creativity. Princeton, NJ: Princeton University Press.

Galenson, D. W. (2005a). Who Are the Greatest Living Artists? The View From the Auction Market. Cambridge, MA: National Bureau of Economic Research. Working paper 11644. Available at: http://www.nber.org/papers/w11644.

Galenson, D. W. (2005b). Toward Abstraction: Ranking European Painters of the Early Twentieth Century. Cambridge, MA: National Bureau of Economic Research. Working paper 11501. Available at: http://www.nber.org/papers/w11501.

Galenson, D. W. (2004). The life cycles of modern artists: Theory and implications. Historical Methods, 37(3), 123-136.

Galenson, D. W. (2003a, Fall). The two life cycles of human creativity. NBER Research, 12-15.

Galenson, D. W. (2003b). The Life Cycles of Modern Artists: Theory, Measurement, and Implications. Cambridge, MA; National Bureau of Economic Research. Available at: http://www.nber.org/papers/w9539

Garfield, E., \& Welljams-Dorof, A. (1992). Of Nobel class: A citation perspective on high impact research authors. Theoretical Medicine, 13(2), 117-135.

Lehman, H. C. (1953). Age and Achievement. Princeton, NJ: Princeton University Press.

Leibovitz, A. (2006, October 2). Quoted in: McGuigan, C. Through her lens. Newsweek, 58-62.

Meho, L. I., \& Spurgin, K. M. (2005). Ranking the research productivity of LIS faculty and schools: An evaluation of data sources and research methods. Journal of the American Society for Information Science and Technology, 56(12), 1314-1331.

Small, H. (1978). Cited documents as concept symbols. Social Studies of Science, 8, 327-340.

Smith, A., \& Eysenck, M. (2002). The Correlation Between RAE Ratings and Citation Counts in Psychology. Available at: http://cogprints.org/2749/ 
Table 1. High-Impact Works and Cumulative Citation Counts

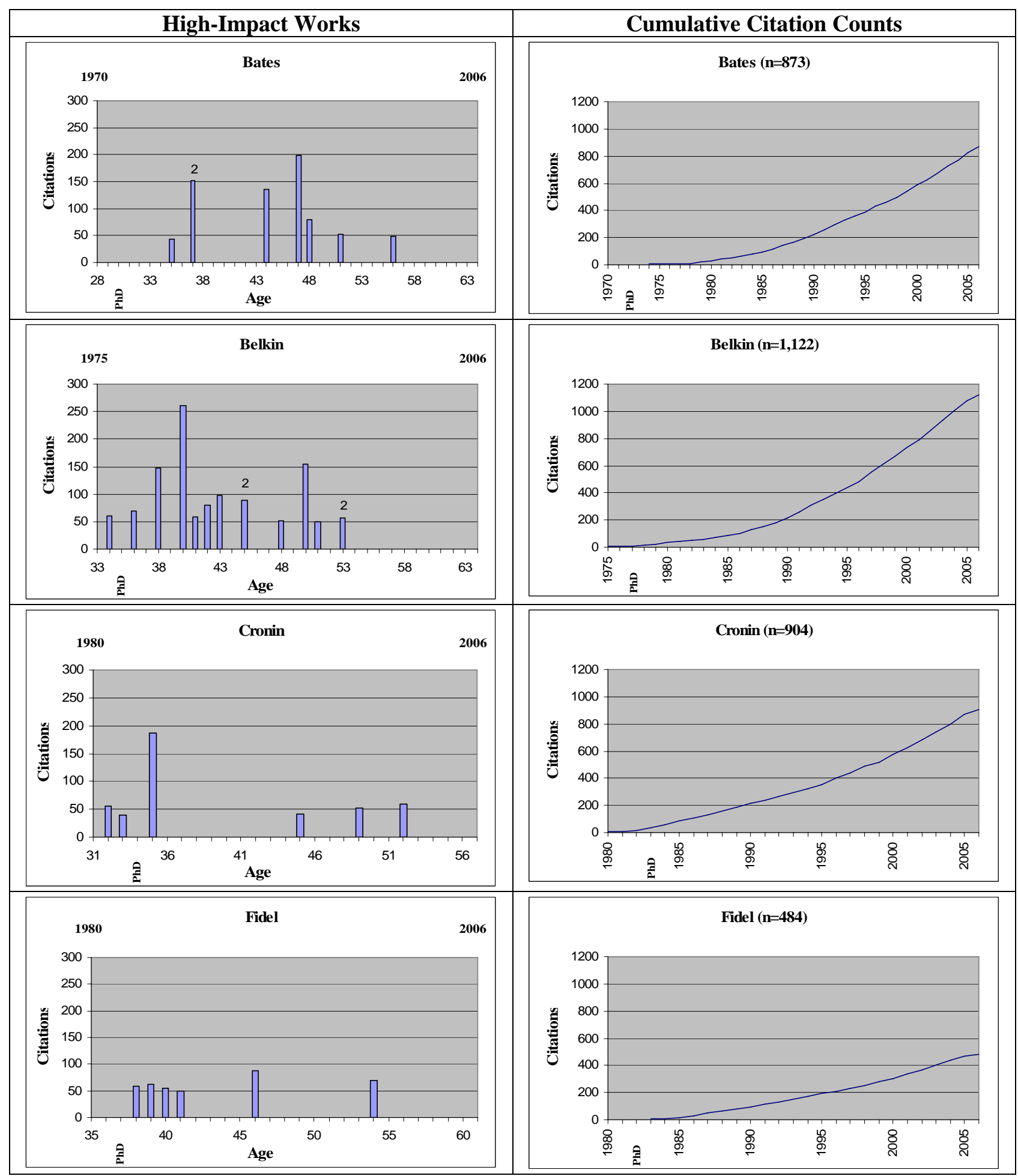




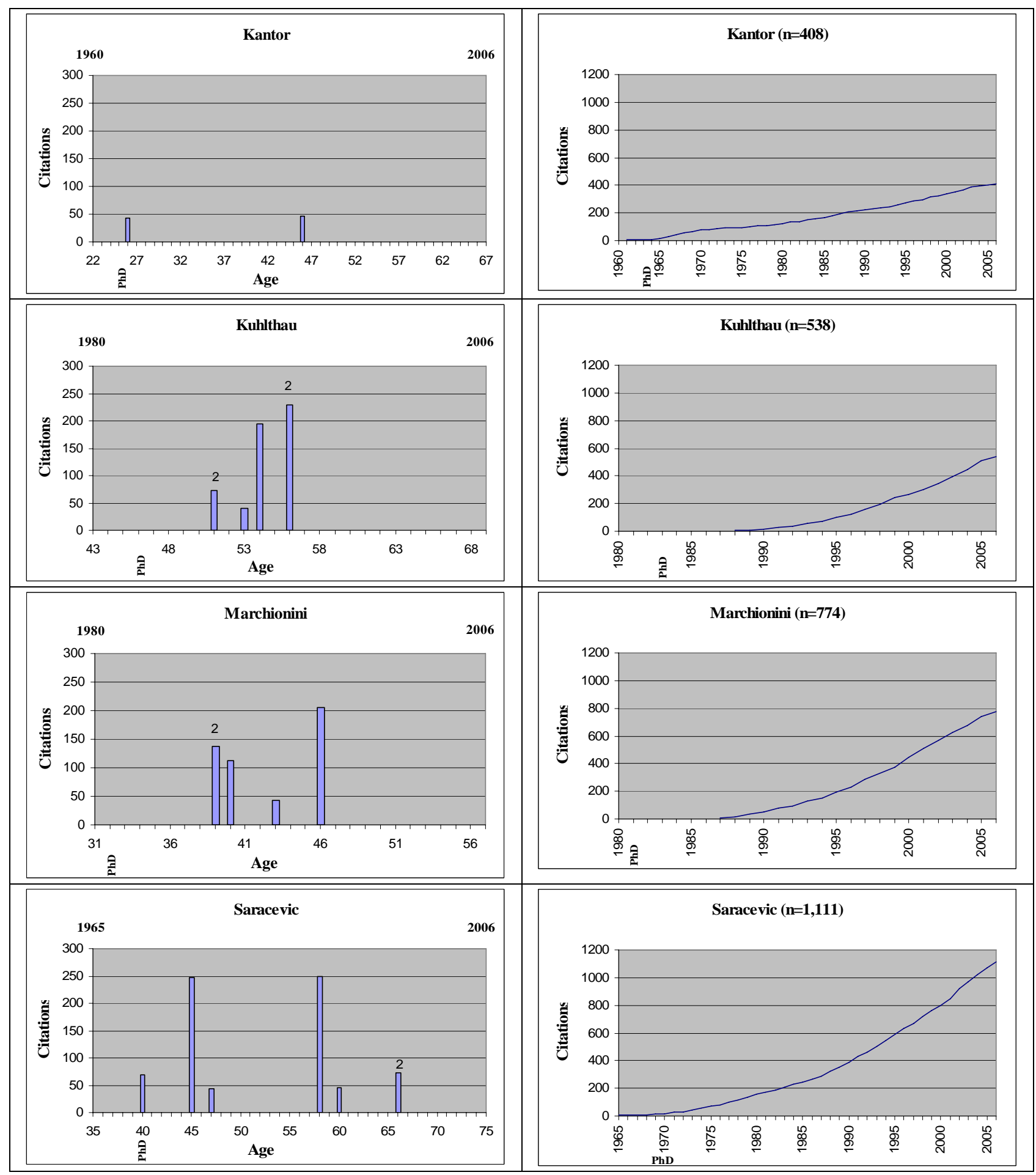






There were nine cases where two highly cited works were published in the same year. These are noted on top of the columns in the charts; in such cases, the height of the column reflects that of the higher cited work. For example, Bates has two highly cited works in 1979: one was cited 74 times and the other 151 times. The column for 1979 shows that there were "2" highly cited works in that year and the higher of the two was cited 151 times. 
Table 2. Proportion of Citations Attributable to Each Author's High-Impact Publications by Stage of Career

\begin{tabular}{|c|c|c|c|c|c|c|}
\hline \multirow{2}{*}{$\begin{array}{l}\text { Author and Total } \\
\text { Citation Count }\end{array}$} & \multicolumn{2}{|c|}{ Early Career } & \multicolumn{2}{|c|}{ Mid-Career } & \multicolumn{2}{|c|}{ Late Career } \\
\hline & $\begin{array}{l}\text { \# high-impact } \\
\text { works }\end{array}$ & $\%$ & $\begin{array}{c}\text { \# high-impact } \\
\text { works }\end{array}$ & $\%$ & $\begin{array}{c}\text { \# high-impact } \\
\text { works* }\end{array}$ & $\%$ \\
\hline Bates (873) & 3 & 23.6 & 3 & 41.8 & $\begin{array}{c}2 \\
(1992)\end{array}$ & 11.5 \\
\hline Belkin $(1,122)$ & 9 & 59.2 & 5 & 29.0 & $\begin{array}{c}- \\
(1998)\end{array}$ & - \\
\hline Cronin (904) & 3 & 28.1 & 3 & 14.6 & $\begin{array}{c}- \\
(2003)\end{array}$ & - \\
\hline Fidel (484) & 5 & 50.8 & 1 & 14.3 & $\begin{array}{c}- \\
(2002)\end{array}$ & - \\
\hline Kantor (408) & 1 & 10.5 & - & - & $\begin{array}{c}1 \\
(1984)\end{array}$ & 11.3 \\
\hline Kuhlthau (538) & 6 & 86.4 & - & - & $\begin{array}{c}- \\
(2003)\end{array}$ & - \\
\hline Marchionini (774) & 3 & 38.0 & 2 & 35.3 & $\begin{array}{c}- \\
(2001)\end{array}$ & - \\
\hline Saracevic $(\mathbf{1 , 1 1 1 )}$ & 3 & 31.1 & 2 & 25.1 & $\begin{array}{c}2 \\
(1990) \\
\end{array}$ & 10.9 \\
\hline Soergel (295) & 1 & 28.8 & 1 & 21.7 & $\begin{array}{c}- \\
(1990)\end{array}$ & - \\
\hline Swanson (797) & 1 & 8.0 & - & 0.0 & $\begin{array}{c}8 \\
(1972) \\
\end{array}$ & 48.3 \\
\hline Tenopir (718) & 1 & 6.5 & 1 & 10.3 & $\begin{array}{c}- \\
(2004)\end{array}$ & - \\
\hline White (595) & 2 & 26.2 & 3 & 36.5 & $\begin{array}{c}2 \\
(1994)\end{array}$ & 23.9 \\
\hline
\end{tabular}

*Year between parentheses represents the date late career started for each author.

This table should be read as follows: Of all 538 citations that Kuhlthau received for all of her publications, $86.4 \%$ of them were to the six high-impact works she published in her early career stage. 
Table 3. Proportion of Citations Attributable to Each Author's High-Impact Publications

\begin{tabular}{|c|c|c|c|c|}
\hline Name & $\begin{array}{l}\text { Total no. of } \\
\text { citations }\end{array}$ & $\begin{array}{l}\text { No. of high- } \\
\text { impact works }\end{array}$ & $\begin{array}{l}\text { No. of times high- } \\
\text { impact works cited }\end{array}$ & $\begin{array}{l}\% \text { of total } \\
\text { citations }\end{array}$ \\
\hline Belkin, Nicholas J. & 1,122 & 14 & 900 & $80.2 \%$ \\
\hline Saracevic, Tefko & 1,111 & 7 & 655 & $59.0 \%$ \\
\hline Cronin, Blaise & 904 & 6 & 362 & $40.0 \%$ \\
\hline Bates, Marcia J. & 873 & 8 & 585 & $67.0 \%$ \\
\hline Swanson, Don R. & 797 & 9 & 438 & $55.0 \%$ \\
\hline Marchionini, Gary & 774 & 5 & 520 & $67.2 \%$ \\
\hline Tenopir, Carol & 718 & 2 & 120 & $16.7 \%$ \\
\hline White, Howard D. & 595 & 7 & 435 & $73.1 \%$ \\
\hline Kuhlthau, Carol C. & 538 & 6 & 465 & $86.4 \%$ \\
\hline Fidel, Raya & 484 & 6 & 309 & $63.8 \%$ \\
\hline Kantor, Paul B. & 408 & 2 & 89 & $21.8 \%$ \\
\hline Soergel, Dagobert & 295 & 2 & 144 & $48.8 \%$ \\
\hline Mean & 718.3 & 6.2 & 419.8 & $58.4 \%$ \\
\hline
\end{tabular}


Table 4. Place of Publication of High-Impact Works

\begin{tabular}{|c|c|}
\hline Source/Publisher Information & Number of Articles \\
\hline Journal of the American Society for Information Science & 22 \\
\hline Journal of Documentation & 6 \\
\hline Annual Review of Information Science and Technology & 3 \\
\hline Information Processing \& Management & 3 \\
\hline Journal of Information Science & 3 \\
\hline Library Quarterly & 3 \\
\hline Online Review & 3 \\
\hline Library \& Information Science Research & 2 \\
\hline Perspectives in Biology and Medicine & 2 \\
\hline Proceedings of the ASIS Annual Meeting & 2 \\
\hline Artificial Intelligence & 1 \\
\hline Bulletin of the Medical Library Association & 1 \\
\hline Canadian Journal of Information Science & 1 \\
\hline CoLIS, conference paper in & 1 \\
\hline College \& Research Libraries & 1 \\
\hline Communications of the ACM & 1 \\
\hline Computer & 1 \\
\hline Educational Technology & 1 \\
\hline Expert Systems with Applications & 1 \\
\hline International Journal of Man-Machine Studies & 1 \\
\hline Physical Review Letters & 1 \\
\hline$R Q$ & 1 \\
\hline Science & 1 \\
\hline Social Science Information Studies & 1 \\
\hline Books & 9 \\
\hline Book chapters & 2 \\
\hline
\end{tabular}




\section{Appendix. High-Impact Works Studied}

\begin{tabular}{|c|c|c|c|c|}
\hline Author & Year & Title & Source/Publisher Information & $\begin{array}{l}\text { Times } \\
\text { Cited }\end{array}$ \\
\hline Bates, M. J. & 1977 & $\begin{array}{l}\text { Factors Affecting Subject Catalog Search } \\
\text { Success }\end{array}$ & $\begin{array}{l}\text { Journal of the American Society for } \\
\text { Information Science, 28(3), 161-169. }\end{array}$ & 44 \\
\hline Bates, M. J. & 1979 & Information Search Tactics & $\begin{array}{l}\text { Journal of the American Society for } \\
\text { Information Science, 30(4), 205-214. }\end{array}$ & 151 \\
\hline Bates, M. J. & 1979 & Idea Tactics & $\begin{array}{l}\text { Journal of the American Society for } \\
\text { Information Science, 30(5), 280-289. }\end{array}$ & 74 \\
\hline Bates, M. J. & 1986 & $\begin{array}{l}\text { Subject Access in Online Catalogs - a Design- } \\
\text { Model }\end{array}$ & $\begin{array}{l}\text { Journal of the American Society for } \\
\text { Information Science, 37(6), 357-376. }\end{array}$ & 136 \\
\hline Bates, M. J. & 1989 & $\begin{array}{l}\text { The Design of Browsing and Berrypicking } \\
\text { Techniques for the Online Search Interface }\end{array}$ & Online Review, 13(5), 407-424. & 199 \\
\hline Bates, M. J. & 1990 & $\begin{array}{l}\text { Where Should the Person Stop and the } \\
\text { Information Search Interface Start }\end{array}$ & $\begin{array}{l}\text { Information Processing \& } \\
\text { Management, 26(5), 575-591. }\end{array}$ & 80 \\
\hline $\begin{array}{l}\text { Bates, M. J., Wilde, D. } \\
\text { N., \& Siegfried, S. }\end{array}$ & 1993 & $\begin{array}{l}\text { An Analysis of Search Terminology Used by } \\
\text { Humanities Scholars - the Getty Online } \\
\text { Searching Project Report-1 }\end{array}$ & Library Quarterly, 63(1), 1-39. & 53 \\
\hline Bates, M. J. & 1998 & $\begin{array}{l}\text { Indexing and Access for Digital Libraries and } \\
\text { the Internet: Human, Database, and Domain } \\
\text { Factors }\end{array}$ & $\begin{array}{l}\text { Journal of the American Society for } \\
\text { Information Science, 49(13), 1185- } \\
1205 .\end{array}$ & 49 \\
\hline $\begin{array}{l}\text { Belkin, N. J., \& } \\
\text { Robertson, S. E. }\end{array}$ & 1976 & $\begin{array}{l}\text { Information-Science and Phenomenon of } \\
\text { Information }\end{array}$ & $\begin{array}{l}\text { Journal of the American Society for } \\
\text { Information Science, 27(4), 197-204. }\end{array}$ & 61 \\
\hline Belkin, N. J. & 1978 & Information Concepts for Information-Science & $\begin{array}{l}\text { Journal of Documentation, 34(1), 55- } \\
85 .\end{array}$ & 69 \\
\hline Belkin, N. J. & 1980 & $\begin{array}{l}\text { Anomalous States of Knowledge as a Basis for } \\
\text { Information-Retrieval }\end{array}$ & $\begin{array}{l}\text { Canadian Journal of Information } \\
\text { Science, 5, 133-143. }\end{array}$ & 147 \\
\hline $\begin{array}{l}\text { Belkin, N. J., Oddy, R. } \\
\text { N., \& Brooks, H. M. }\end{array}$ & 1982 & $\begin{array}{l}\text { Ask for Information-Retrieval. 1. Background } \\
\text { and Theory; 2. Results of a Design Study }\end{array}$ & $\begin{array}{l}\text { Journal of Documentation, 38(2), 61- } \\
\text { 71; 38(3), 145-164. }\end{array}$ & 261 \\
\hline $\begin{array}{l}\text { Belkin, N. J., Seeger, T., } \\
\text { \& Wersig, G. }\end{array}$ & 1983 & $\begin{array}{l}\text { Distributed Expert Problem Treatment as a } \\
\text { Model for Information-System Analysis and } \\
\text { Design }\end{array}$ & $\begin{array}{l}\text { Journal of Information Science, 5(5), } \\
\text { 153-167. }\end{array}$ & 58 \\
\hline Belkin, N. J. & 1984 & Cognitive Models and Information-Transfer & $\begin{array}{l}\text { Social Science Information Studies, } \\
4(2-3), 111-129 .\end{array}$ & 80 \\
\hline Belkin, N. J. & 1985 & $\begin{array}{l}\text { Interaction in Information Systems: A Review } \\
\text { of Research From Document Retrieval to } \\
\text { Knowledge-Based Systems }\end{array}$ & London: British Library. & 97 \\
\hline $\begin{array}{l}\text { Belkin, N. J., \& Croft, W. } \\
\text { B. }\end{array}$ & 1987 & Retrieval Techniques & $\begin{array}{l}\text { Annual Review of Information Science } \\
\text { and Technology, 22, 109-145. }\end{array}$ & 89 \\
\hline $\begin{array}{l}\text { Belkin, N. J., Brooks, H. } \\
\text { M., \& Daniels, P. J. }\end{array}$ & 1987 & $\begin{array}{l}\text { Knowledge Elicitation Using Discourse } \\
\text { Analysis }\end{array}$ & $\begin{array}{l}\text { International Journal of Man-Machine } \\
\text { Studies, 27(2), 127-144. }\end{array}$ & 53 \\
\hline Belkin, N. J. & 1990 & $\begin{array}{l}\text { The Cognitive Viewpoint in Information- } \\
\text { Science }\end{array}$ & $\begin{array}{l}\text { Journal of Information Science, 16(1), } \\
\text { 11-15. }\end{array}$ & 52 \\
\hline $\begin{array}{l}\text { Belkin, N. J., \& Croft, W. } \\
\text { B. }\end{array}$ & 1992 & $\begin{array}{l}\text { Information Filtering and Information- } \\
\text { Retrieval - } 2 \text { Sides of the Same Coin }\end{array}$ & $\begin{array}{l}\text { Communications of the ACM, 35(12), } \\
\text { 29-38. }\end{array}$ & 155 \\
\hline $\begin{array}{l}\text { Belkin, N. J., Marchetti, } \\
\text { P. G., \& Cool, C. }\end{array}$ & 1993 & $\begin{array}{l}\text { Braque - Design of an Interface to Support } \\
\text { User Interaction in Information-Retrieval }\end{array}$ & $\begin{array}{l}\text { Information Processing \& } \\
\text { Management, 29(3), 325-344. }\end{array}$ & 50 \\
\hline
\end{tabular}




\begin{tabular}{|c|c|c|c|c|}
\hline $\begin{array}{l}\text { Belkin, N. J., Cool, C., } \\
\text { Stein, A., \& Thiel, U. }\end{array}$ & 1995 & $\begin{array}{l}\text { Cases, Scripts, and Information-Seeking } \\
\text { Strategies - on the Design of Interactive } \\
\text { Information-Retrieval Systems }\end{array}$ & $\begin{array}{l}\text { Expert Systems with Applications, } \\
\text { 9(3), 379-395. }\end{array}$ & 56 \\
\hline $\begin{array}{l}\text { Belkin, N. J., Kantor, P., } \\
\text { Fox, E. A., \& Shaw, J. A. }\end{array}$ & 1995 & $\begin{array}{l}\text { Combining the Evidence of Multiple Query } \\
\text { Representations for Information-Retrieval }\end{array}$ & $\begin{array}{l}\text { Information Processing \& } \\
\text { Management, 31(3), 431-448. }\end{array}$ & 48 \\
\hline Cronin, B. & 1981 & The Need for a Theory of Citing & $\begin{array}{l}\text { Journal of Documentation, 37(1), 16- } \\
24 .\end{array}$ & 55 \\
\hline Cronin, B. & 1982 & $\begin{array}{l}\text { Invisible Colleges and Information Transfer: A } \\
\text { Review and Commentary with Particular } \\
\text { Reference to the Social-Sciences }\end{array}$ & $\begin{array}{l}\text { Journal of Documentation, 38(3), 212- } \\
236 .\end{array}$ & 40 \\
\hline Cronin, B. & 1984 & $\begin{array}{l}\text { The Citation Process: The Role and } \\
\text { Significance of Citations in Scientific } \\
\text { Communication }\end{array}$ & London: Taylor Graham. & 186 \\
\hline $\begin{array}{l}\text { Cronin, B., \& Overfelt, } \\
\text { K. }\end{array}$ & 1994 & $\begin{array}{l}\text { Citation-Based Auditing of Academic- } \\
\text { Performance }\end{array}$ & $\begin{array}{l}\text { Journal of the American Society for } \\
\text { Information Science, 45(2), 61-72. }\end{array}$ & 41 \\
\hline Cronin, B., et al. & 1998 & Invoked on the Web & $\begin{array}{l}\text { Journal of the American Society for } \\
\text { Information Science, 49(14), 1319- } \\
1328 .\end{array}$ & 52 \\
\hline Cronin, B. & 2001 & $\begin{array}{l}\text { Bibliometrics and Beyond: Some Thoughts on } \\
\text { Web-Based Citation Analysis }\end{array}$ & $\begin{array}{l}\text { Journal of Information Science, 27(1), } \\
1-7 .\end{array}$ & 60 \\
\hline Fidel, R., \& Soergel, D. & 1983 & $\begin{array}{l}\text { Factors Affecting Online Bibliographic } \\
\text { Retrieval: A Conceptual-Framework for } \\
\text { Research }\end{array}$ & $\begin{array}{l}\text { Journal of the American Society for } \\
\text { Information Science, 34(3), 163-180. }\end{array}$ & 58 \\
\hline Fidel, R. & 1984 & $\begin{array}{l}\text { Online Searching Styles: A Case-Study-Based } \\
\text { Model of Searching Behavior }\end{array}$ & $\begin{array}{l}\text { Journal of the American Society for } \\
\text { Information Science, 35(4), 211-221. }\end{array}$ & 62 \\
\hline Fidel, R. & 1985 & Moves in Online Searching & Online Review, 9(1), 61-74. & 55 \\
\hline Fidel, R. & 1986 & $\begin{array}{l}\text { Towards Expert Systems for the Selection of } \\
\text { Search Keys }\end{array}$ & $\begin{array}{l}\text { Journal of the American Society for } \\
\text { Information Science, 37(1), 37-44. }\end{array}$ & 50 \\
\hline Fidel, R. & 1991 & $\begin{array}{l}\text { Searchers Selection of Search Keys. 1. The } \\
\text { Selection Routine; 2. Controlled Vocabulary or } \\
\text { Free-Text Searching; 3. Searching Styles }\end{array}$ & $\begin{array}{l}\text { Journal of the American Society for } \\
\text { Information Science, 42(7), 490-500; } \\
\text { 42(7), 501-514; 42(7), 515-527. }\end{array}$ & 88 \\
\hline Fidel, R., et al. & 1999 & $\begin{array}{l}\text { A Visit to the Information Mall: Web } \\
\text { Searching Behavior of High School Students }\end{array}$ & $\begin{array}{l}\text { Journal of the American Society for } \\
\text { Information Science, 50(1), 24-37. }\end{array}$ & 69 \\
\hline Kantor, P. B. & 1964 & $\begin{array}{l}\text { Nucleon-Nucleon Scattering + Meson } \\
\text { Resonances }\end{array}$ & Physical Review Letters, 12(2), 52-\&. & 43 \\
\hline Kantor, P. B. & 1984 & $\begin{array}{l}\text { Objective Performance Measures for } \\
\text { Academic and Research Libraries }\end{array}$ & $\begin{array}{l}\text { Washington, D.C.: Association of } \\
\text { Research Libraries. }\end{array}$ & 46 \\
\hline Kuhlthau, C. C. & 1988 & $\begin{array}{l}\text { Developing a Model of the Library Search } \\
\text { Process: Cognitive and Affective Aspects }\end{array}$ & $R Q, 28(2), 232-242$ & 72 \\
\hline Kuhlthau, C. C. & 1988 & $\begin{array}{l}\text { Longitudinal Case Studies of the Information } \\
\text { Search Process of Users in Libraries }\end{array}$ & $\begin{array}{l}\text { Library \& Information Science } \\
\text { Research, 10(3), 257-304. }\end{array}$ & 44 \\
\hline $\begin{array}{l}\text { Kuhlthau, C. C., Turock, } \\
\text { B. J., George, M. W., \& } \\
\text { Belvin, R. J. }\end{array}$ & 1990 & $\begin{array}{l}\text { Validating a Model of the Search Process: A } \\
\text { Comparison of Academic, Public and School } \\
\text { Library Users }\end{array}$ & $\begin{array}{l}\text { Library \& Information Science } \\
\text { Research, 12(1), 5-31. }\end{array}$ & 40 \\
\hline Kuhlthau, C. C. & 1991 & $\begin{array}{l}\text { Inside the Search Process: Information Seeking } \\
\text { from the Users Perspective }\end{array}$ & $\begin{array}{l}\text { Journal of the American Society for } \\
\text { Information Science, 42(5), 361-371. }\end{array}$ & 194 \\
\hline Kuhlthau, C. C. & 1993 & $\begin{array}{l}\text { A Principle of Uncertainty for Information- } \\
\text { Seeking }\end{array}$ & $\begin{array}{l}\text { Journal of Documentation, 49(4), 339- } \\
355 .\end{array}$ & 64 \\
\hline
\end{tabular}




\begin{tabular}{|c|c|c|c|c|}
\hline Kuhlthau, C. C. & 1993 & $\begin{array}{l}\text { Seeking Meaning: A Process Approach to } \\
\text { Library and Information Services }\end{array}$ & Norwood, NJ: Ablex Pub. Corp. & 229 \\
\hline Marchionini, G. & 1988 & $\begin{array}{l}\text { Hypermedia and Learning: Freedom and } \\
\text { Chaos }\end{array}$ & Educational Technology, 28(11), 8-12. & 59 \\
\hline $\begin{array}{l}\text { Marchionini, G., \& } \\
\text { Shneiderman, B. }\end{array}$ & 1988 & $\begin{array}{l}\text { Finding Facts Vs Browsing Knowledge in } \\
\text { Hypertext Systems }\end{array}$ & Computer, 21(1), 70-80. & 138 \\
\hline Marchionini, G. & 1989 & $\begin{array}{l}\text { Information-Seeking Strategies of Novices } \\
\text { Using a Full-Text Electronic Encyclopedia }\end{array}$ & $\begin{array}{l}\text { Journal of the American Society for } \\
\text { Information Science, 40(1), 54-66. }\end{array}$ & 112 \\
\hline Marchionini, G. & 1992 & Interfaces for End-User Information Seeking & $\begin{array}{l}\text { Journal of the American Society for } \\
\text { Information Science, } 43(2), 156-163 .\end{array}$ & 43 \\
\hline Marchionini, G. & 1995 & $\begin{array}{l}\text { Information Seeking in Electronic } \\
\text { Environments }\end{array}$ & Cambridge University Press. & 206 \\
\hline Saracevic, $\mathrm{T}$. & 1970 & Introduction to Information Science & New York: R.R. Bowker Co. & 70 \\
\hline Saracevic, T. & 1975 & $\begin{array}{l}\text { Relevance: Review of and a Framework for } \\
\text { Thinking on Notion in Information Science }\end{array}$ & $\begin{array}{l}\text { Journal of the American Society for } \\
\text { Information Science, 26(6), 321-343. }\end{array}$ & 248 \\
\hline $\begin{array}{l}\text { Saracevic, T., Shaw, W. } \\
\text { M., \& Kantor, P. B. }\end{array}$ & 1977 & $\begin{array}{l}\text { Causes and Dynamics of User Frustration in an } \\
\text { Academic Library }\end{array}$ & $\begin{array}{l}\text { College \& Research Libraries, 38(1), } \\
\text { 17-18. }\end{array}$ & 44 \\
\hline $\begin{array}{l}\text { Saracevic, T., Kantor, P., } \\
\text { Chamis, A. Y., \& } \\
\text { Trivison, D. }\end{array}$ & 1988 & $\begin{array}{l}\text { A Study of Information Seeking and } \\
\text { Retrieving. 1. Background and Methodology; } \\
\text { 2. Users, Questions, and Effectiveness; } 3 . \\
\text { Searchers, Searches, and Overlap }\end{array}$ & $\begin{array}{l}\text { Journal of the American Society for } \\
\text { Information Science, 39(3), 161-176; } \\
\text { 39(3), 177-196; 39(3), 197-216. }\end{array}$ & 249 \\
\hline $\begin{array}{l}\text { Saracevic, T., Mokros, } \\
\text { H., \& Su, L. }\end{array}$ & 1990 & $\begin{array}{l}\text { Nature of Interaction between Users and } \\
\text { Intermediaries in Online Searching: A } \\
\text { Qualitative Analysis }\end{array}$ & $\begin{array}{l}\text { Proceedings of the ASIS Annual } \\
\text { Meeting, 27, 47-54. }\end{array}$ & 46 \\
\hline Saracevic, T. & 1996 & $\begin{array}{l}\text { Modeling Interaction In Information Retrieval } \\
\text { (IR): A Review and Proposal }\end{array}$ & $\begin{array}{l}\text { Proceedings of the ASIS Annual } \\
\text { Meeting, 33, 3-9. }\end{array}$ & 59 \\
\hline Saracevic, T. & 1996 & Relevance Reconsidered & $\begin{array}{l}\text { Conceptions of library and } \\
\text { information science: integration in } \\
\text { perspective: CoLIS } 2 \text { - International } \\
\text { conference. Copenhagen: Royal } \\
\text { School of Librarianship. }\end{array}$ & 72 \\
\hline Soergel, D. & 1974 & $\begin{array}{l}\text { Indexing Languages and Thesauri: } \\
\text { Construction and Maintenance }\end{array}$ & Los Angeles: Melville Pub. Co. & 85 \\
\hline Soergel, D. & 1985 & $\begin{array}{l}\text { Organizing Information: Principles of Data } \\
\text { Base and Retrieval Systems }\end{array}$ & Orlando, Fla.: Academic Press. & 64 \\
\hline Swanson, D. R. & 1960 & $\begin{array}{l}\text { Searching Natural Language Text by } \\
\text { Computer. Machine Indexing and Text } \\
\text { Searching Offer an Approach to the Basic } \\
\text { Problems of Library Automation }\end{array}$ & Science, 132, 1099-1104. & 64 \\
\hline Swanson, D. R. & 1977 & $\begin{array}{l}\text { Information Retrieval as a Trial-and-Error } \\
\text { Process }\end{array}$ & Library Quarterly, 47(2), 128-148. & 81 \\
\hline Swanson, D. R. & 1986 & Undiscovered Public Knowledge & Library Quarterly, 56(2), 103-118. & 64 \\
\hline Swanson, D. R. & 1986 & $\begin{array}{l}\text { Fish Oil Raynaud's Syndrome and } \\
\text { Undiscovered Public Knowledge }\end{array}$ & $\begin{array}{l}\text { Perspectives in Biology and Medicine, } \\
\text { 30(1), 7-18. }\end{array}$ & 91 \\
\hline Swanson, D. R. & 1987 & $\begin{array}{l}\text { Two Medical Literatures That Are Logically } \\
\text { but Not Bibliographically Connected }\end{array}$ & $\begin{array}{l}\text { Journal of the American Society for } \\
\text { Information Science, 38(4), 228-233. }\end{array}$ & 56 \\
\hline Swanson, D. R. & 1988 & $\begin{array}{l}\text { Historical Note: Information Retrieval and the } \\
\text { Future of an Illusion }\end{array}$ & $\begin{array}{l}\text { Journal of the American Society for } \\
\text { Information Science, 39(2), 92-98. }\end{array}$ & 67 \\
\hline Swanson, D. R. & 1988 & $\begin{array}{l}\text { Migraine and Magnesium Eleven Neglected } \\
\text { Connections }\end{array}$ & $\begin{array}{l}\text { Perspectives in Biology and Medicine, } \\
\text { 31(4), 526-566. }\end{array}$ & 79 \\
\hline
\end{tabular}




\begin{tabular}{|c|c|c|c|c|}
\hline Swanson, D. R. & 1990 & $\begin{array}{l}\text { Medical Literature as a Potential Source of } \\
\text { New Knowledge }\end{array}$ & $\begin{array}{l}\text { Bulletin of the Medical Library } \\
\text { Association, 78(1), 29-37. }\end{array}$ & 49 \\
\hline $\begin{array}{l}\text { Swanson, D. R., \& } \\
\text { Smalheiser, N. R. }\end{array}$ & 1997 & $\begin{array}{l}\text { An Interactive System for Finding } \\
\text { Complementary Literatures: A Stimulus to } \\
\text { Scientific Discovery }\end{array}$ & Artificial Intelligence, 91(2), 183-203. & 88 \\
\hline Tenopir, C. & 1985 & Full Text Database Retrieval Performance & Online Review, 9(2), 149-164. & 47 \\
\hline Tenopir, C. K. D. W. & 2000 & $\begin{array}{l}\text { Towards Electronic Journals: Realities for } \\
\text { Scientists, Librarians, and Publishers }\end{array}$ & $\begin{array}{l}\text { Washington, DC: Special Libraries } \\
\text { Association. }\end{array}$ & 74 \\
\hline $\begin{array}{l}\text { White, H. D., \& Griffith, } \\
\text { B. C. }\end{array}$ & 1981 & $\begin{array}{l}\text { Author Cocitation: A Literature Measure of } \\
\text { Intellectual Structure }\end{array}$ & $\begin{array}{l}\text { Journal of the American Society for } \\
\text { Information Science, 32(3), 163-171. }\end{array}$ & 146 \\
\hline $\begin{array}{l}\text { White, H. D., \& Griffith, } \\
\text { B. C. }\end{array}$ & 1982 & $\begin{array}{l}\text { Authors as Markers of Intellectual Space: Co- } \\
\text { Citation in Studies of Science, Technology and } \\
\text { Society }\end{array}$ & $\begin{array}{l}\text { Journal of Documentation, 38(4), 255- } \\
272 .\end{array}$ & 40 \\
\hline $\begin{array}{l}\text { White, H. D., \& McCain, } \\
\text { K. W. }\end{array}$ & 1989 & Bibliometrics & $\begin{array}{l}\text { Annual Review of Information Science } \\
\text { and Technology, 24, 119-186. }\end{array}$ & 125 \\
\hline White, H. D. & 1990 & $\begin{array}{l}\text { Author Co-Citation Analysis: Overview and } \\
\text { Defense }\end{array}$ & $\begin{array}{l}\text { In C.L. Borgman (Ed.), Scholarly } \\
\text { communication and bibliometrics (pp. } \\
\text { 84-106). Newbury Park: Sage } \\
\text { Publications. }\end{array}$ & 58 \\
\hline White, H. D. & 1994 & $\begin{array}{l}\text { Scientific Communication and Literature } \\
\text { Retrieval }\end{array}$ & $\begin{array}{l}\text { In The Handbook of research synthesis } \\
\text { (pp. 41-55). New York: Russell Sage } \\
\text { Foundation. }\end{array}$ & 52 \\
\hline $\begin{array}{l}\text { White, H. D., \& McCain, } \\
\text { K. W. }\end{array}$ & 1997 & Visualization of Literatures & $\begin{array}{l}\text { Annual Review of Information Science } \\
\text { and Technology, 32, 99-168. }\end{array}$ & 49 \\
\hline $\begin{array}{l}\text { White, H. D., \& McCain, } \\
\text { K. W. }\end{array}$ & 1998 & $\begin{array}{l}\text { Visualizing a Discipline: An Author Co- } \\
\text { Citation Analysis of Information Science, } \\
\text { 1972-1995 }\end{array}$ & $\begin{array}{l}\text { Journal of the American Society for } \\
\text { Information Science, 49(4), 327-355. }\end{array}$ & 121 \\
\hline
\end{tabular}

